\title{
O "espaço do fabuloso" e a representação de animais na cerâmica coríntia no século VII a.C.
}

\author{
Alexandre Carneiro Cerqueira Lima ${ }^{[1]}$
}

\begin{abstract}
Resumo
A representação de animais na cerâmica coríntia durante o VII século a.C. consiste em uma temática bastante apreciada entre arqueólogos e historiadores da Arte ao longo do século XX. Segundo esses especialistas, o 'estilo orientalizante' era concebido como uma 'importação' de signos próximo-orientais por parte dos artesãos gregos. Porém, uma nova visão acerca do 'fenômeno orientalizante' tem buscado compreender as tensões, as disputas e os conflitos no seio das elites nas póleis por meio da análise dos artefatos 'orientais'. Nosso intuito consiste em apresentar um novo olhar sobre as representações de animais e de 'seres fabulosos' na cerâmica coríntia durante o VII século a.C.

Palavras-chave: “fenômeno orientalizante”, cerâmica coríntia, animais.
\end{abstract}

\section{El "spacio del fabuloso" y la representación de animales en la cerámica coríntia en el siglo VII a. C.}

\section{Resumen}

A representação de animais na cerâmica coríntia durante o século VII século a. C. consiste em uma temática bastante apreciada entre arqueólogos e historiadores da Arte ao longo do século XX. Segundo esses especialistas, o "estilo orientalizante" era concebido como uma "importação" de signos próximo-orientais por parte dos artesãos gregos. Porém, uma nova visão acerca do "fenômeno orientalizante" tem buscado compreender as tensões, as disputase os conflitos no seio das elites nas póleis por meio da análise dos artefatos orientais. Nosso intuito consiste em apresentar um novo olhar sobre as representações de animais e de "seres fabulosos" na cerâmica coríntia durante o século VII a.C. - deixar o VII século a. C.

Palabras-clave: "fenômeno orientalizante", cerâmica coríntia, animais.

\section{The "fantastic space" and the representation of animals in the corinthian pottery} in the $7^{\text {th }}$ century B.C.

\begin{abstract}
The representation of animals in the corinthian pottery during the 7th century BC consists in a thematic well appreciated among archaeologists and historians of art of the 20th century. According to those specialists, the "orientalizing style" was conceived as an "importation" of symbols of the near east by the greek artisans. Nevertheless, a new interpretation of the "orientalizing phenomenon" searches to comprehend the tensions, contests and conflicts within the poliad elites through the analysis of the "oriental" artifacts. Our aim is to present a new look about the representations of animals and "fantastic beings" in the corithian pottery of the 7th century B.C.
\end{abstract}

Keywords: "orientalizing phenomenon", corithian pottery, animals.

\section{"L'espace du fabuleux" et la representation d'animaux dans la céramique Corinthienne pendant le VII'ème siècle avantJ-C.}

\section{Résumé}

La représentation d'animaux dans la céramique Corinthienne pendant le VIIème siècle avant J-C. est une thématique très appréciée des Archéologues et des Historiens de l’Art tout au long du XXème siècle. Selon ces spécialistes, le ‘style à l'orientale' était vu comme une 'importation' des signes du proche-orient faite par les artisans Grecs. Cependant, une nouvelle approche du ' phénomène orientalisant' cherche à comprendre les tensions, les disputes et les conflits au sein des élites dans les polis à travers l'analyse des objets 'orientaux.' Notre but est de présenter un nouveau regard sur les représentations d' animaux et 'd'êtres fabuleux' dans la céramique Corinthienne du VIIème siècle avant J-C. Mots-clé: "phénomène orientalisant", céramique Corinthienne, animaux. 


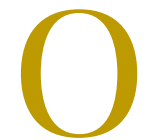

presente artigo tem como objetivo compreender as representações de animais na cerâmica coríntia. A passagem do estilo protocoríntio de pintura para o coríntio ilustra bem as disputas entre os grupos de aristocratas por meio das representações pictóricas nas cerâmicas produzidas pelas olarias do Istmo de Corinto. Irei identificar em alguns vasos a representação de seres híbridos mesclados com a de animais e de heróis populares na região da pólis de Corinto. Para tal, dividi o trabalho em duas partes, a saber: 1 - O espaço dos animais nos estilos protocoríntio e coríntio de pinturas; 2 - O "espaço do fabuloso": um tópos privilegiado de encontro de animais, de seres híbridos e de heróis.

\section{O espaço dos animais nos estilos protocoríntio e coríntio de pinturas}

Quando olhamos para as cenas pintadas nos vasos de estilo protocoríntio de pintura, identificamos uma profusão de animais e seres híbridos/fantásticos. Já no estilo coríntio de pintura, tais signos não serão mais os "protagonistas" prediletos dos pintores do Istmo. ${ }^{2}$ Eles protagonizavam as superfícies de aryballoi e de alabastros no estilo protocoríntio, contudo, passaram a ser desenhados nas bordas, nas asas e em frisos secundários no estilo coríntio de pintura. Essa mudança me intriga, pois, apesar de eles terem sido transferidos para as "margens" ou "periferias" dos vasos, tais signos continuam a preencher a superfície do suporte cerâmico e irão fazer parte de uma narrativa pictórica extremamente variada, conectados com cenas de banquete, de kômos, de heróis, de divindades e de outras práticas sociais. ${ }^{3}$

Em uma recente pesquisa, François Lissarrague identificou que nas representações de sátiros na cerâmica ática de figuras vermelhas, os pintores poderiam representá-los nos "limites" e nas "margens" dos vasos. Segundo Lissarrague, a imagem eclipsa o limite entre decoração e figuração, entre ornamento e representação (Lissarague, 2013, p. 59). Essa constatação é importante para tentar vincular a pintura de signos animalescos com temas do estilo de pintura coríntio.

Devo esclarecer que tais signos, em minha análise, portam sentido e significados tanto para os pintores quanto para os usuários dos vasos. Não os leio como simples ornamentos decorativos (Lima, 2014). Eles compõem uma narrativa pictórica e formam um sintagma. Cabe, portanto, agora, explicitar os animais e seres fabulosos representados nos dois estilos de pintura.

Galo, cabrito-montês, cão, cavalo, leão e pantera são os bichos mais representados (Kardianou, 2009, p. 63-74). Quanto aos seres híbridos e fabulosos, posso listar a esfinge, as sereias, o grifo e a górgona. Todos esses animais e seres

\footnotetext{
2Seguiremos a periodização apresentada por Anne Coulié sobre os estilos protocoríntio e coríntio de pinturas: Protocoríntio Antigo (720-690 a.C.), Protocoríntio Médio (690-645/640 a.C.), Protocoríntio Recente (640-630 a.C.), Coríntio Antigo (620-580 a.C.) e Coríntio Médio (590-570 a.C.). Coulié (2013, p. 105-141).

33ugerimos ao leitor interessado duas propostas metodológicas para a análise das imagens de vasos gregos, a saber: Bérard (1983,p. 5-37); Lissarrague (2013).
} 
híbridos aparecem nos estilos protocoríntio e coríntio de pinturas, e ambos os estilos são próprios do VII século e da "arte orientalizante". Mas no que consiste o "estilo orientalizante"?

Tradicionalmente, historiadores da arte e arqueólogos definiam a "arte" arcaica e, em especial, a "arte" do VII século a.C. como "orientalizante". Autores renomados, tais como John Boardman, R. M. Cook e Humpry Payne, apontaram temáticas e signos importados do Oriente Próximo (da Assíria, da Fenícia e do Egito) por parte dos artesãos gregos (Payne, 1931; Cook, 1997; Boardman, 1965). Estes assimilaram animais e seres fantásticos em suas obras. Payne esclarece que os artífices do Istmo de Corinto foram os pioneiros no processo de assimilação de esquemas pictóricos orientais. Segundo o arqueólogo, a representação do leão, por exemplo, no estilo protocoríntio seria de inspiração hitita. Contudo, no estilo coríntio de pintura, o motivo viria da região da Assíria (Payne, 1931, p. 67).

\section{Galo, cabrito-montês, cão, cavalo, leão e pantera são os bichos mais representados}

Nos últimos anos, os estudos dedicados à "arte" do VII século a.C. mudaram significativamente. $\mathrm{O}$ "fenômeno orientalizante" abarca várias manifestações artísticas e sociais. Difusão da escrita, pintura e artesanato expressam bem o contato entre as culturas gregas e próximo-orientais. Como Javier de $\mathrm{Hoz}$ explica, o "fenômeno orientalizante" consiste essencialmente no encontro de pessoas de culturas diferentes em um contexto de navegação e de exploração das potencialidades do mar (comércio, "colonização", pirataria); da transferência de técnicas artesanais e de circulação desses artesãos em culturas distintas. Hoz alerta também para o fato de que o "fenômeno orientalizante" ocorre em sociedades com um certo tipo de desenvolvimento econômico e com elites poderosas que"controlam"4 esse desenvolvimento. As elites "dos príncipes na Itália, os aristocratas na Grécia ou os reinos centralizados com uma nobreza opulenta como na Frígia (...)" (Hoz, 2010, p. 84).Javier de Hoz acredita na força e na pujança das elites que podem estimular até mesmo o deslocamento de artesãos. O etruscólogo Mario Torelli acentua a circulação de artesãos coríntios na Etrúria, disseminando técnicas e esquemas pictóricos (Torelli, 1999, p. 122).

A difusão do "orientalizante" pode ser bem atestada nas oferendas de santuários, tanto regionais quanto pan-helênicos. Muitas vezes, é difícil detectar se um objeto é de fato oriental ou possui inspiração oriental. Um santuário, como o de Delfos, pode ser palco de disputas e de rivalidades entre as elites gregas por meio das oferendas de artefatos "orientalizantes". Tais oferendas

${ }^{4}$ Deixei o verbo empregado pelo autor (contrôlent), porém creio que em tal processo de criação, consumo e difusão colaboram vários outros fatores, um deles é a métis, astúcia, inteligência prática do artesão e também do consumidor. 
resultam em um conjunto de escolhas feitas pelos cultuadores, utilizando uma certa "imagem" do Oriente, "aquela que corresponde às práticas sociais aristocráticas" com um claro objetivo de construir seu prestígio e sua identidade (Aurigny, 2010, p. 248). Portanto, em um contexto sagrado de um santuário pan-helênico, as oferendas de prestígio permitem ao dedicador afirmar sua identidade e posicionamento social, graças à origem e à forma dos objetos (Hoffman; Brisart, 2010, p. 249).

No imaginário helênico ou no das elites nas póleis, o Oriente representava o luxo, o refinamento, um modo de vida sedutor. Os banquetes e a prática da hospitalidade - forjadores de laços de amizade entre as elites - marcariam o estilo de vida dos áristoi. Catherine Saint-Pierre Hoffmann e Thomas Brisart afirmam que: "A estética orientalizante permite a esse grupo desenvolver uma identidade comum e reforçar a sua coesão" (Hoffman; Brisart, 2010, p. 250).Esta prática nos leva a pensar que existe uma circulação entre pessoas, ou seja, os helenos recebem os estrangeiros vindos do Oriente e os hospeda e vice-versa. Daí o cuidado do anfitrião em receber o hóspede amigo em sua casa rodeada de objetos familiares com o objetivo de deixá-lo à vontade. A prática do banquete promovia relações entre amigos em diversos grupos sociais que ultrapassava os limites da vizinhança e da pólis.

No tocante à produção de artefatos, Francis Croissant marca bem a "diversidade" das respostas e das reações dos artesãos diante do "fenômeno orientalizante (Croissant, 2010, p. 335)". O autor não acredita em um "estilo orientalizante" único e homogêneo nas oficinas de Creta, de Atenas, da Eubeia ou mesmo nas de Corinto. Ao contrário, cada uma dessas culturas reagiu de forma diferenciada ao "estilo oriental", de acordo com sua trajetória histórica (navegação, comércio e colonização). Croissant acredita que a criação de uma "identidade estilística", por parte de cada cultura, representa a "afirmação calculada de uma diferença” (Croissant, 2010, p. 330). Isso quer dizer que as respostas dos ateliers gregos ao "fenômeno orientalizante" são marcadas pela diferença e pela heterogeneidade, ou seja, um processo de transmissão e de difusão bastante complexos. Nesse sentido, Croissant compreende que a competição atingia as esferas da produção e também do consumo de artefatos "orientalizantes". Segundo o autor: "A lógica agonal característica da cultura grega aqui atuou em um papel decisivo" (Croissant, 2010, p. 336).

E, nesse processo agonal, de disputas, não podemos esquecer da relação emissor - receptor, do pintor e de sua clientela. Dessa forma, encaro tais assimilações e trocas em uma perspectiva de consumo, muito próxima à noção de tática sugerida por Michel de Certeau ${ }^{5}$ (Certeau, 1996, p. 47). Não é um consumo passivo; pelo contrário, tanto os artesãos gregos quanto os da Etrúria irão utilizar de forma específica e diferenciada os signos "orientais".

\footnotetext{
${ }_{5}^{5}$ Michel de Certeau baseia-se na noção de métis (ardil/astúcia) estudada por Marcel Detienne e Jean-Pierre Vernant para compreender as transgressões cotidianas cometidas pelos consumidores, ou seja, "pequenos sucessos, artes de dar golpes, astúcias de 'caçadores' (...) Essas performances operacionais dependem de saberes muito antigos. Os gregos as designavam pela métis." Ver Detienne (2008)..
} 
Portanto, o processo criativo dos artesãos em suas oficinas, como o "gosto" e o consumo por parte da clientela, consiste em elementos de uma complexa equação. Vários fatores devem ser considerados para uma melhor compreensão dessas atividades (criação artesanal/consumo). O artesão grego não assimilava passivamente os esquemas pictóricos orientais e sua clientela (gregos e etruscos, por exemplo) usava e lia de forma diferenciada os artefatos e imagens "orientalizantes".

Quando observamos os vasos de estilo protocoríntio, verificamos que os animais e "seres fabulosos" são os protagonistas na superfície cerâmica. Entretanto, no estilo coríntio de pintura, animais e seres fantásticos irão para as margens/limites do suporte cerâmico e em meados do VI século começam a escassear. No próximo item, podemos constatar tal mudança na Cratera $\mathrm{E}$ 635 do Museu do Louvre. Nesse artefato, a representação dos animais foi deslocada para a boca do artefato.

\section{O "espaço do fabuloso": um tópos privilegiado de encontro de animais, de seres híbridos e de heróis}

O pintor de vasos domiciliado no Bairro dos Oleiros, situado na ásty de Corinto,

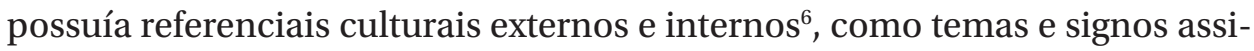
milados do Oriente Próximo, além de referenciais da própria cultura em que o artífice está imerso, ou seja, a da pólis dos coríntios do período arcaico. Mas como podemos identificar tais referenciais em uma pólis com poucos testemunhos escritos? Uma possibilidade consiste em mapear tais referenciais em sua "paisagem religiosa". Lugares e espaços sagrados no Istmo de Corinto permitem vislumbrar não só a ocupação do território, mas também as representações forjadas por seus habitantes em relação às espacialidades. Podemos lembrar da Acrópole de Corinto, conhecida como Heliopólis, espaço sagrado saturado de representações relacionadas aos mitos de fundação da pólis. Hélios, em disputa com Poseidon pela posse de Corinto, sai vencedor e se apodera do centro cultual na ásty da pólis. Porém, ao percorrer o Istmo, percebemos na “paisagem religiosa", a presença marcante da divindade perdedora ${ }^{7}$. Poseidon é a divindade cultuada no santuário do Istmo, voltado para o Oriente, bem como é presença no porto de Léchaion, voltado para o Ocidente. Poseidon,

\footnotetext{
${ }^{6}$ Partimos do pressuposto de que o artesão em sua oficina está conectado tanto com tendências estrangeiras quanto com referenciais de sua própria cultura. Creio que as pesquisas de AbyWarburg e de Carlo Ginzburg avançaram bastante a respeito desse aspecto. Warburg (2013); Ginzburg (2014).

7“Falar de 'lugares' é limitar-se a estudar as coisas uma por uma na sua singularidade; para ir além disso é preciso questionar nossos próprios conceitos, diferenciando em cada um deles o que pode contribuir para a análise das realidades antigas. As noções de espaço e de paisagem merecem assim ser confrontadas, espelhadas no estudo dos fatos religiosos. A priori, em nosso sistema de representações, a noção de espaço parece mais abstrata e mais construída; ela introduz um certo grau de organização consciente, enquanto que a ideia de paisagem é mais associada a uma percepção visual e parece ser construída a partir de lugares com suas próprias características. (...) Mais do que a noção de espaço, o conceito de paisagem engloba uma parte de visão e portanto de representação. É por isso que ela pode fazer referência a vários níveis de representação, que não são estranhos um em relação ao outro mas que não se confundem. Podemos falar de paisagem religiosa para caracterizar o modo como os Antigos percebiam a presença de forças superiores em diferentes lugares." Polignac (2014, p. 9).
} 
nesses dois santuários, transita entres as esferas da equitação (da domesticação do cavalo e dos jogos pan-helênicos) e da navegação. E, por último, no santuário de Penteskouphia, situado a sudoeste da ásty de Corinto, Poseidon é divindade de navegantes e de comerciantes. Sua presença nesse último santuário foi atestada pelas placas de argila (pinax) encontradas no témenos do santuário. No mapa a seguir, podemos identificar as divindades cultuadas na pólis dos coríntios.

Partindo dos arranjos politeístas forjados pelos coríntios (Detienne, 2000), verificamos que as representações pictóricas criadas pelos artesãos do Istmo estavam estreitamente relacionadas às suas escolhas de divindades. Os animais e "seres fabulosos" pintados nos vasos fazem parte desse repertório de referenciais e povoavam o imaginário dos coríntios nos VII e VI séculos a.C.

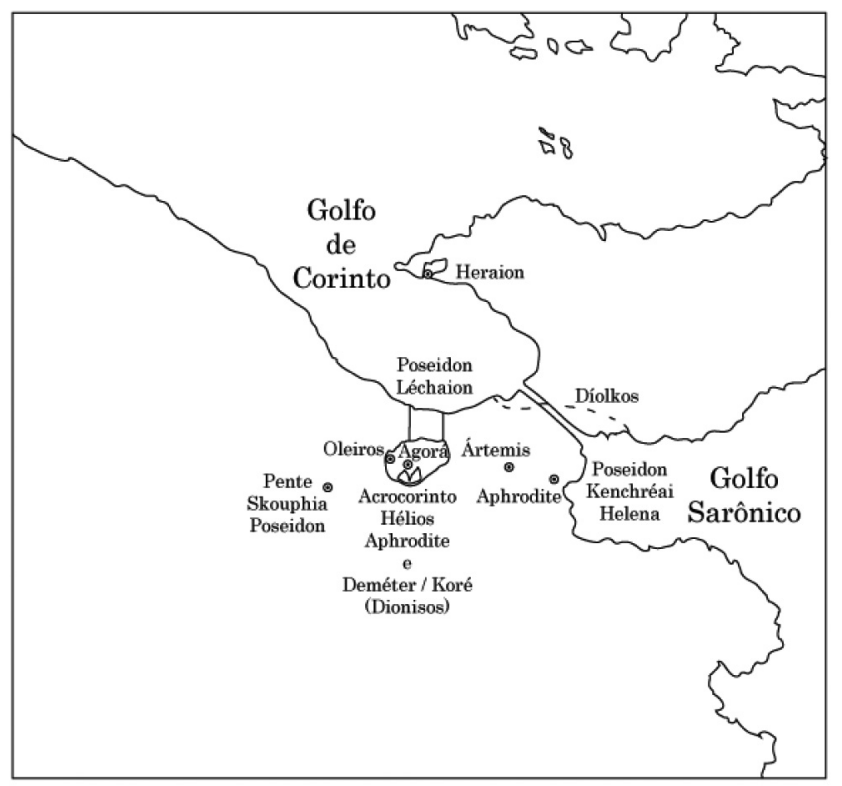

Figura 1: Mapa da região do Istmo de Corinto.

Poseidon, por exemplo, aparece nas placas votivas de Penteskouphia, com seu tridente e sua esposa Amphitrite. Nos vasos, há uma presença marcante da representação de cavalos, peixes e golfinhos ${ }^{8}$ (Aristóteles, História dos Animais, VIII, 2 (591 b); IX, 48 (631 a)). Nereu, o Velho do Mar, foi representado em uma kylix junto com cavalos, golfinhos e Gorgó no medalhão da taça. Lembremos que a cabeleira de Górgona nos remete às crinas dos cavalos e representava a passagem para o mundo do Hades (Daraki, 1982, p. 8). Portanto, as potências relacionadas à equitação, navegação e passagem para o mundo subterrâneo estão conectadas e aparecem tanto nas espacialidades do Istmo quanto no imaginário dos coríntios.

${ }^{8}$ Os golfinhos são os mais velozes dos seres aquáticos, eles possuem uma natureza doce e amável, além de os casais viverem juntos (machos e fêmeas). 
Na taça abaixo, vislumbramos todos esses signos misturados na pintura do artesão. As representações em torno das potências marinhas e do Hades reiteram o destaque dado pelos pintores do Istmo a Poseidon, golfinhos e cava$\operatorname{los}^{9}$.Vale ressaltar também que o cavalo e o golfinho são signos de passagem, o primeiro na terra e o segundo nos mares.

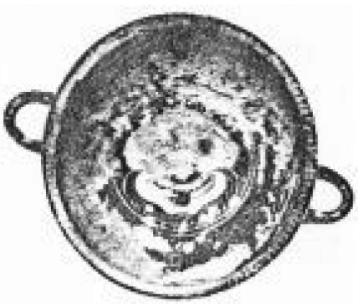

Figura 2a: Medalhão da taça coríntia: Górgona.

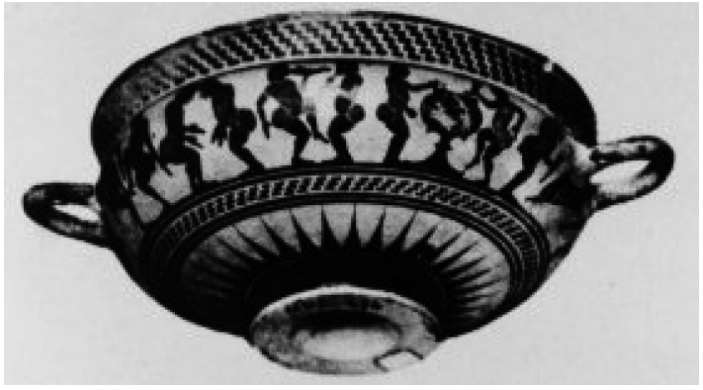

Figura 2b: Taça coríntia: kômos.

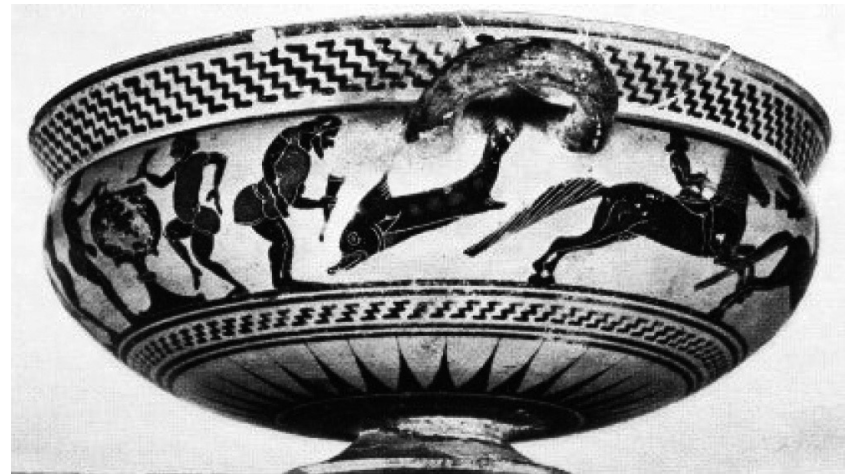

Figura 2c: Asa com representação de golfinho e de cavaleiros. 


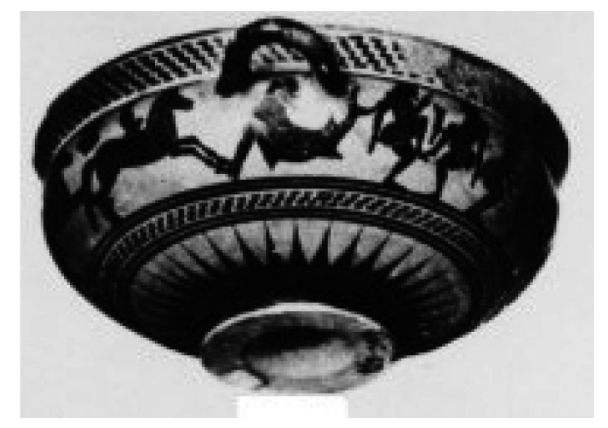

Figura 2d: Asa com representação de Nereu/golfinho.

Aphrodite é outra divindade bastante presente no imaginário dos pintores domiciliados no Istmo de Corinto. No mapa, podemos identificar a presença de Aphrodite na Acrocorinto, em um santuário próximo do Porto de Kenchréai (voltado para o Oriente), bem como na agorá, no espaço urbano (Dubini, 2011, p. 96). A pantera, animal "importado" do repertório pictórico oriental, transita entre as esferas dionisíaca e da deusa do amor. A pantera pode expressar as ideias de caça, caça amorosa, prostituição, selvageria e sedução. É um animal frequente tanto em pequenos vasos (aryballoi), pratos, quanto nas grandes crateras. Ela é sempre representada em destaque, por exemplo, no centro dos frisos das crateras e com olhar frontal. Esse olhar marca a infração à regra do olhar de perfil (comunicação interna da cena pintada). O rosto da pantera com olhar frontal forma uma máscara (prosopon) sedutora e mortífera. De acordo com Aristóteles, a pantera exala um perfume que inebria as suas presas ${ }^{10}$ (Aristóteles, História dos Animais, IX, 1 (608 a); IX, 6 (612 a)). A seguir, veremos um alabastro que sintetiza bem as características da pantera no imaginário coríntio por meio dos signos que explicitam a sedução, a caça e a selvageria ${ }^{11}$ (Seeberg, 1971, p. 41).
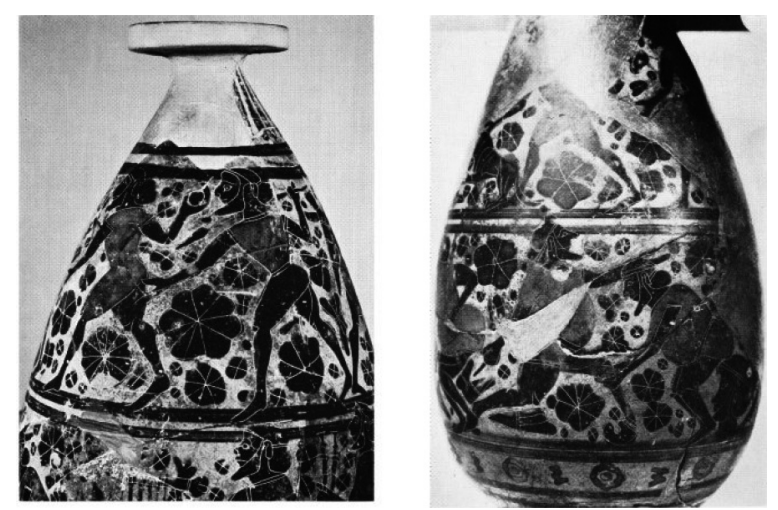

Figura 3a: Alabastro coríntio com cenas de caça e de kômos.

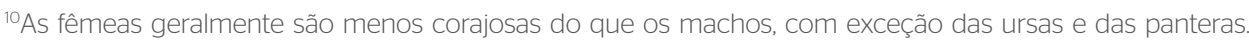
Os animais amam sentir o odor exalado pela pantera, ela se oculta e, ao se aproximarem, a pantera os caça, assim como acontece com os cervos.

"Alabastro coríntio. Estilo antigo de pintura coríntia, c. 625-600 a. C. Museu do Louvre. No. S. 1104.
} 

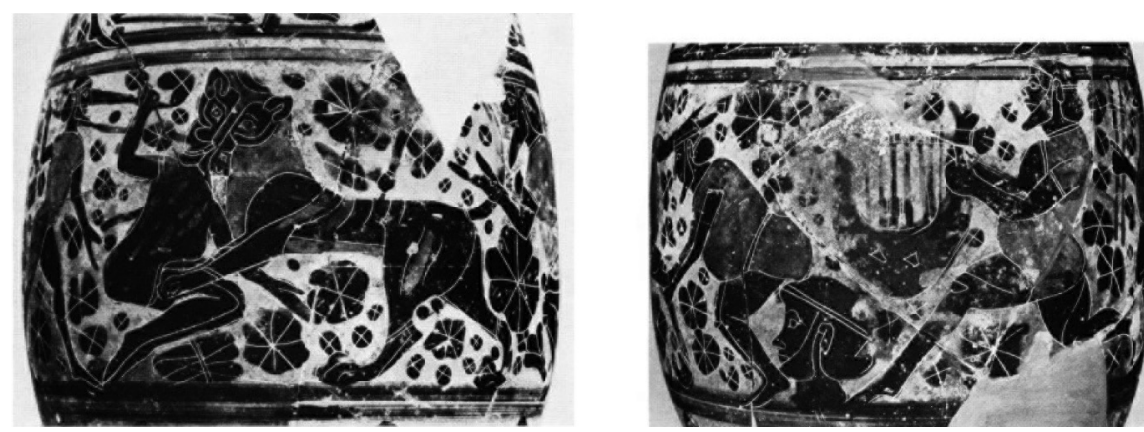

Figura 3b: Detalhes do mesmo alabastro com representação de pantera/caçador e de kômos.

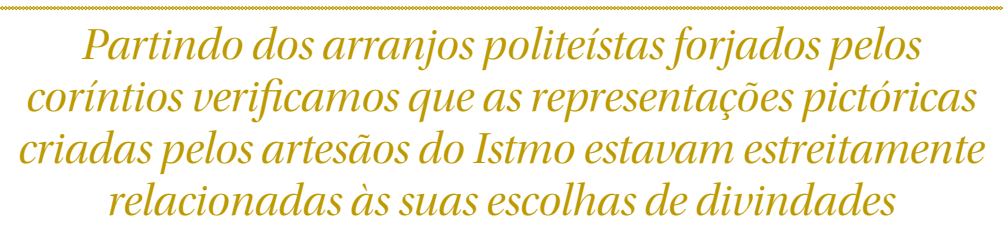

Após apresentar esses dois artefatos, gostaria de refletir acerca da noção de "espaço do fabuloso" em um outro vaso. Tal "espaço" permitiria aflorar as noções de paideia (formação/educação), de andreia (coragem/virilidade), de aguçar a métis, a criatividade e o contato com o Outro, o "selvagem", o "diferente". Na cratera coríntia E $635^{12}$ (Pottier, 1897, p. 56) conhecida como Cratera de Eurytos, exposta no Museu do Louvre, podemos identificar várias ideias levantadas no presente trabalho. Inicialmente, partiremos da descrição das cenas no artefato: quatro klínai com mesas à frente guarnecidas com iguarias (prato contendo dois bolos ou manjares em forma de pirâmide), taças e outros utensílios difíceis de identificar. Sob cada mesa, encontra-se um cão atado com uma corda ao pé do leito. Os convivas estão reclinados sobre os leitos e cada um deles foi identificado pelo pintor por meio das inscrições em alfabeto coríntio. O primeiro leito abriga os irmãos Toxos (imberbe) e Klytios (barbado),e este passa a taça para os familiares do leito ao lado. Nessa klíne, o pintor representou pai e filho: Didaion e Eurytos. O primeiro provavelmente segura um alimento em sua mão esquerda e com a mão direita apanha uma taça da mesa; o seu pai Eurytos segura com a mão esquerda uma phiále. Reclinado e sozinho no leito seguinte, encontra-se Íphitos, tendo em sua mão esquerda um alimento (?) e sua mão direita está na taça apoiada à mesa (trapédza). Voltada para seu irmão - Íphitos - em pé, vemos Íole. Na extremidade da cena, vislumbramos Héracles

${ }^{12}$ Cratera coríntia encontrada em Caere. Estilo antigo de pintura coríntia, c. 625-600 a. C. Museu do Louvre, E 635 
sozinho em sua klíne, voltado para o resto do grupo, com sua mão esquerda segurando um alimento, já a da direita, uma mákhaira (faca sacrificial ${ }^{13}$ ).

Continuando a cena, abaixo das asas, vemos os sacrificadores retalhando a vítima. O mais alto é barbado e passa para o jovem (imberbe) um pernil de animal. Entre os dois, há uma espécie de mesa onde estão depositados os pedaços de carne. À esquerda do sacrificador barbado, podemos observar um dinos (cratera sem asas) com uma oenocho é na boca do grande vaso. A face $B$ consiste em um registro de guerra: um arqueiro atirando flechas, três duplas de hoplitai se enfrentando e, por fim, mais um arqueiro. Sob a outra asa, foi identificado o tema do suicídio de Ájax: Diomedes e Odisseus, ambos com a panóplia hoplítica e, entre eles, o corpo de Ájax caído no chão (todos identificados por meio de inscrições em coríntio). O seu corpo encontra-se atravessado por uma espada, cujo cabo está cravado na terra e percebe-se jorrar o sangue da ferida. No friso inferior, foram representados onze efebos cavalgando e somente um é seguido pelo pássaro voando. Na parte plana da asa (na boca do vaso) da direita, dois efebos cavalgam em seus cavalos; na outra parte da oreillette, segundo Pottier (Pottier, 1897, p. 56), um homem nu crava sua lança nas ancas de uma corça que foge à direita (Esopo, 104 'A Corça e o leão num antro'), junto de um cervo; o sangue jorra da ferida. Na boca do vaso, estão figurados os seguintes animais: panteras, corça, leões, esfinges, cisnes, cães, lebres e pássaros.

\section{A pantera pode expressar as ideias de caça, caça amorosa, prostituição, selvageria e sedução}

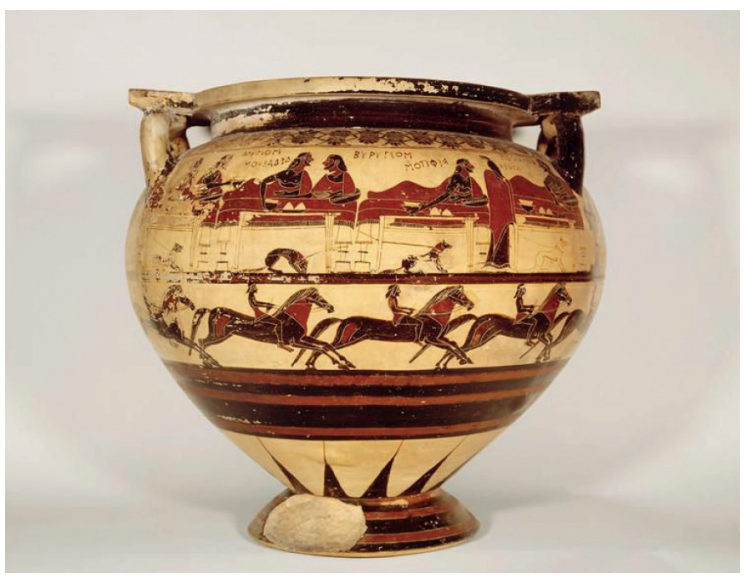

Figura 4: Cratera E 635 - banquete e cavaleiros.

\footnotetext{
${ }^{13} \mathrm{O}$ autor J. L. Durand explica que em seu corpus de imagens sobre o sacrifício de bois, a faca sacrificial mákhaira - era mais utilizada do que o machado - pélekus. Este artefato foi representado em um alábastros coríntio: Berlin VI 3419; NC, p. 283, nº 362.
} 


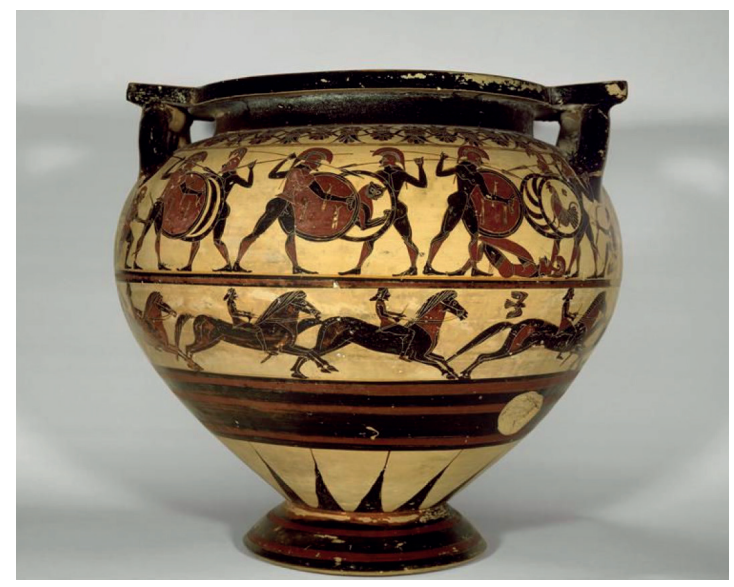

Figura 4b: hoplitas e cavaleiros.
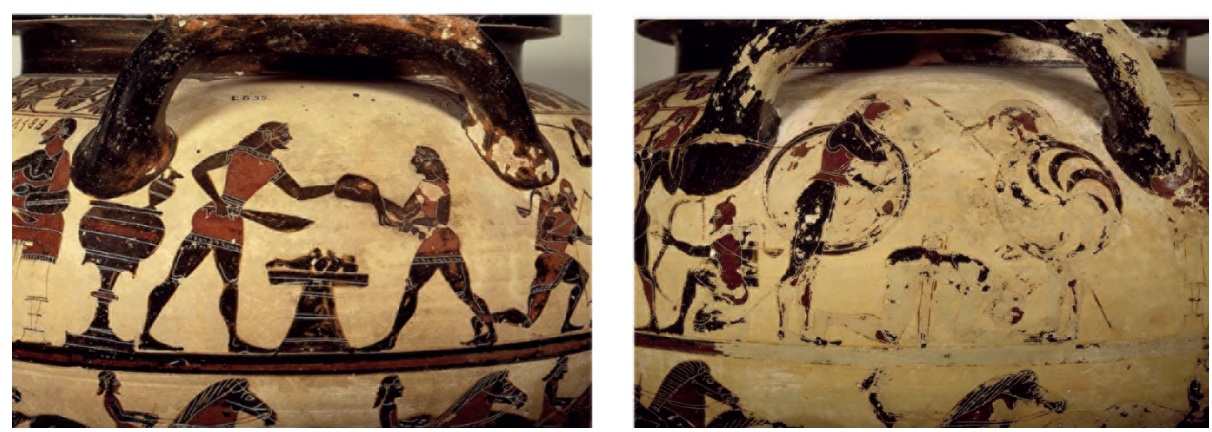

Figura 4c: Cenas representadas abaixo das asas - sacrificador e suicídio de Ájax.

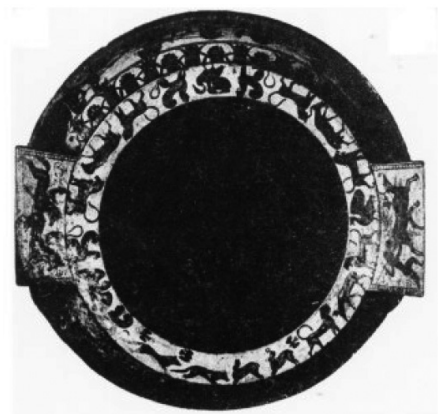

Figura 4c: Boca da Cratera E 635 com representação de animais e "seres fabulosos".

Na Cratera de Eurytos, um verdadeiro bestiário é representado. Nessa cratera, fica patente a escolha do pintor em colocar animais representados em frisos secundários (cavalos), nas extremidades e "margens" do vaso (animais na parte plana da orelha e da boca da cratera). Entretanto, esses signos são bastante importantes para compreendermos o sintagma, ou seja, o significado das cenas do vaso. Os animais pintados tanto na parte plana das orelhas e na boca reiteram a ideia de caça, do contato homem versus besta. A caça mítica ao leão, 
assimilada do Oriente ${ }^{14}$ (Aristóteles, História dos Animais, VIII, 28), bem como a caça relacionada aos ritos iniciáticos dos jovens com a representação de cães e corças (Vidal-Naquet, 2005, p. 169), estão mescladas com a caça amorosa, marcada pela presença da pantera e da lebre (Schnapp, 1984). Além disso, um ser híbrido oriental, a esfinge, também foi representada na boca da cratera. A esfinge aflora a ideia de alteridade, de contato com o Outro e com o diferente.

Todos esses animais e seres fabulosos foram representados na boca do vaso. Um usuário do vaso, ao olhá-lo de cima, irá vislumbrar a representação circular desses animais "dançando" em torno do vinho. O conviva apanha vinho na cratera com seres que evocam a caça, o contato com o Outro e a sedução. Portanto, o "espaço do fabuloso", nas margens/limites da cratera contribuem significativamente para mergulharmos no criativo imaginário dos artesãos coríntios do período arcaico.

A apreciação da Cratera de Eurytos nos estimula a pensar na representação de heróis mesclados com animais e seres "fantásticos" na imagética coríntia. De acordo com Anne Coulié, os heróis mais pintados pelos artífices do Istmo foram Belerofonte e Héracles. Belerofonte "descendente da casa real de Corinto. Filho de Poseidon, tem por pai 'humano' Glauco, o filho de Sísifo" (Grimal, 2005, p. 59). Portanto, ele estava intrinsicamente conectado com o repertório mítico da pólis. Filho de uma das mais cultuadas divindades do panteão coríntio: Poseidon, como já mostramos, era cultuado em, pelo menos, três santuários dispersos no território da pólis. Além de sua privilegiada filiação, Belerofonte, em sua trajetória mítica, tinha raízes profundas com as espacialidades de Corinto. O herói, em uma certa ocasião, encontrou, junto à Fonte Peirenne, localizada na ásty de Corinto, o cavalo alado Pégasos e foi graças à parceria com a besta voadora que Belerofonte matou o "monstro" Quimera (ser híbrido: leão/cabra e serpente na parte de trás) (Aghion, 2008, p. 67).Fica patente aqui que, no imaginário coríntio, os animais e "seres fabulosos" estavam mesclados a deuses e heróis, tanto nos relatos de poetas e mitógrafos, quanto nas imagens dos pintores do "Bairro dos Oleiros".

Abaixo, podemos vislumbrar um prato de cerca de 580 a.C. com a representação da Quimera ${ }^{15}$ (Coulié, 2013, p. 136).

\footnotetext{
${ }^{14}$ De acordo com o relato do filósofo Aristóteles, o leão poderia ser encontrado na Líbia e na Europa, entre os rios Achelóos e Néssos. Em contrapartida, a pantera só poderia ser encontrada na Ásia e jamais na Europa. ${ }^{15}$ Prato coríntio. Estilo médio de pintura coríntia, c. 580 a. C. Museu do Louvre. L 143-L 52.
} 


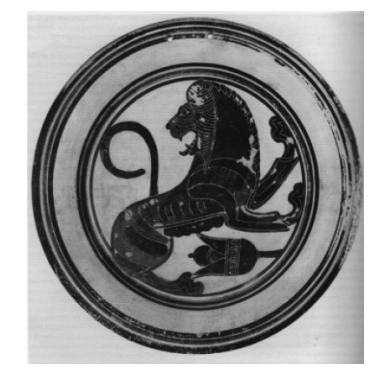

Figura 5: Prato com a representação da Quimera.

Além de Belerofonte, Héracles foi outro herói bastante representado na cerâmica coríntia. Acima, constatamos sua presença na Cratera de Eurytos e o tema da hospitalidade. Da mesma forma que Belerofonte, o filho de Zeus também foi traçado junto com "criaturas fabulosas". Em vários cotyloi, o semideus aparece lutando contra a Hydra de Lerna e centauros.

No cótylo ${ }^{16}$ abaixo, artefato encontrado na Ática e datado entre 600-575 a.C., aparece em uma extremidade o herói Héracles (próximo aos seus dois cavalos e o carro) acompanhado de seu fiel Iolaos, que abatem a Hydra de Lerna (Hesíodo, Teogonia, vv. 313-319). Cinco komástai representados foram nomeados (da esquerda para a direita): "Curvado", “Gracioso", "Agradável (?)", "Folião/Komastési" e"Inclinado" (Seeberg, 1971, p. 38). Somente o komastés que apanha vinho no dinos não foi nomeado. Entre o carro e Héracles, o vaso encontra-se fragmentado. De acordo com D. A. Amyx é Athená (inscrição danificada) representada segurando um vaso para "refrescar Héracles após a batalha" (Amyx, 1983, p. 48). A deusa Athená ajudou o herói em sua empreitada contra a Hydra (Mossé, p. 155). A Hydra é um serpente das águas que vive no rio Evénos, segundo Sófocles (Sófocles, As Traquínias, vv. 560-565), ou em região pantanosa $^{17}$ (Bélis, 1998, p. 778-780). Assim sendo, Héracles, ao matá-la, está exercendo a sua tarefa civilizatória: ele transforma a natureza, o local pantanoso em um lugar cultivável ${ }^{18}$ (Theml, 2000). Daí a alegria dos komástai, evidenciada pelos seus passos e também pelas inscrições. Kómios é o folião no centro dos dançarinos. Todos festejam alegremente a passagem da selvageria (Hydra) para a cultura (Héracles). Não é à toa que, entre os heróis, o pintor representou dois vasos: a oenochoé e o dinos. Ambos servem para manipular, transportar e servir o vinho misturado - aspecto da cultura. Só os sátyroi e bárbaros bebem o vinho puro (Lissarague, 1987, p. 11). A representação do dinos também nos remete para o espaço público em virtude desse vaso ser usado para transportar a bebida dionisíaca, especialmente nas festas dos camponeses.

\footnotetext{
${ }^{16}$ Cótylo coríntio encontrado na Ática. Estilo médio de pintura coríntia, c. 570 a. C. Museu do Louvre. CA 3004. ${ }^{17}$ De acordo com os estudos de Annie Bélis, em Corinto, havia ergasthérion, onde eram fabricadas flautas. Para confeccionar esses instrumentos, as oficinas deveriam estar situadas em regiões pantanosas abundantes em caniços. Corinto tinha a reputação de produzir bons instrumentos de sopro (utilizando também o bronze). ${ }^{18 S}$ Sobre o herói Héracles: "Héracles tem como virtudes a coragem, a força e seus trabalhos, em sua maioria estavam vinculados a implementação do pastoreio e da agricultura (...) Graças a Héracles, os homens reconhecem, pelos ritos de sacrifício de boi, que são produtores de alimentos: cereais e carne de animal doméstico. Ao aprender a sacrificar os animais aos deuses, o homem se destaca da vida selvagem e do nomadismo. Os ritos de sacrifício dos animais transformam a carne em alimento". Esse artigo foi anteriormente publicado na revista Humanitas, Vol. XLVII, 1995, p. 71-80.
} 


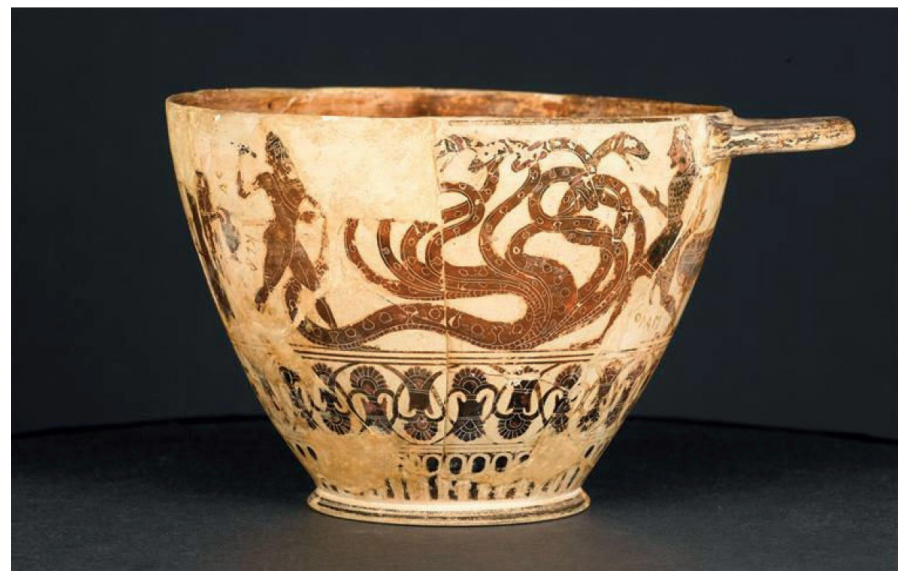

Figura 6a: Cótylo coríntio com representação de Héracles e daHydra.

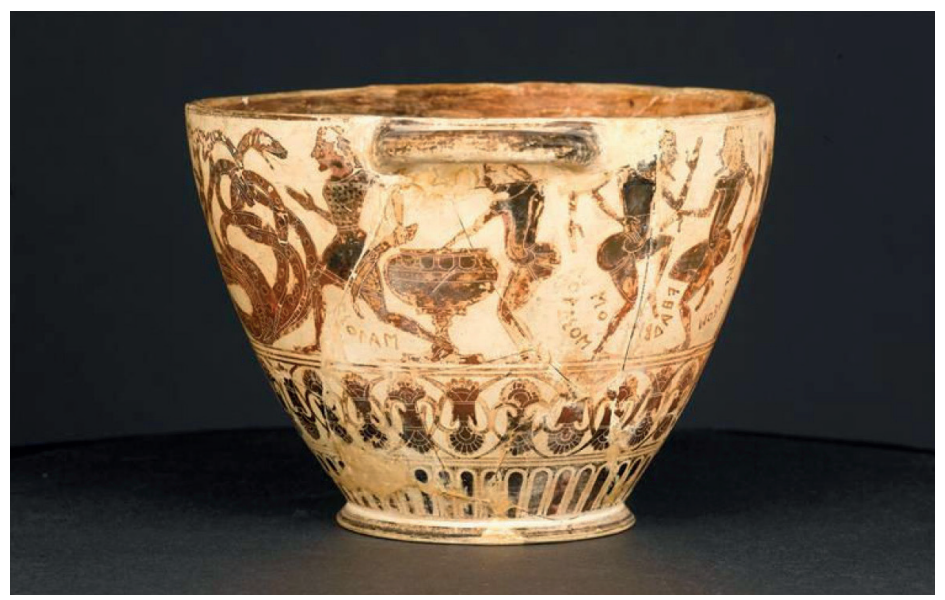

Figura 6b: Hydra, lolaos, a representação de um dinos e kômos.

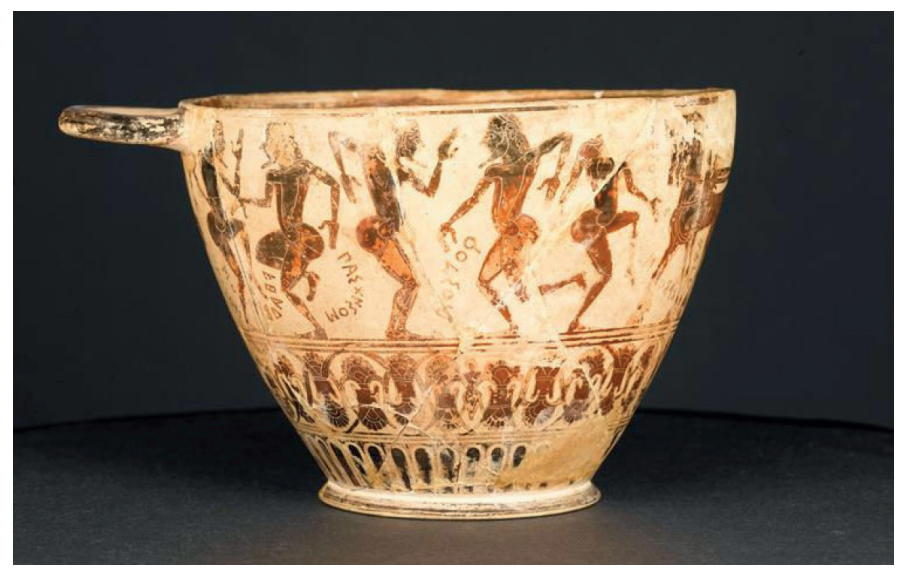

Figura 6c: Kômos 
Em outros vasos, os pintores do Istmo representaram Héracles lutando contra centauros. Em um cótylo do Museu do Louvre ${ }^{19}$, por exemplo, o episódio representado remete à passagem de Héracles na gruta do centauro Pholos. Trata-se da caça aos centauros "loucos em virtude do odor do vinho" (Coulié, 2013, p. 138). Esses três últimos artefatos reiteram, portanto, a estreita relação entre animais/"seres fabulosos" com os heróis cultuados no Istmo de Corinto. Além disso, explicitam aspectos da espacialidade da própria pólis. Fontes, rios, pântanos e o campo são evocados juntos com as entidades fantásticas. Todos esses signos fazem parte do imaginário dos cidadãos e dos artesãos domiciliados na pólis de Corinto no VII século a.C.
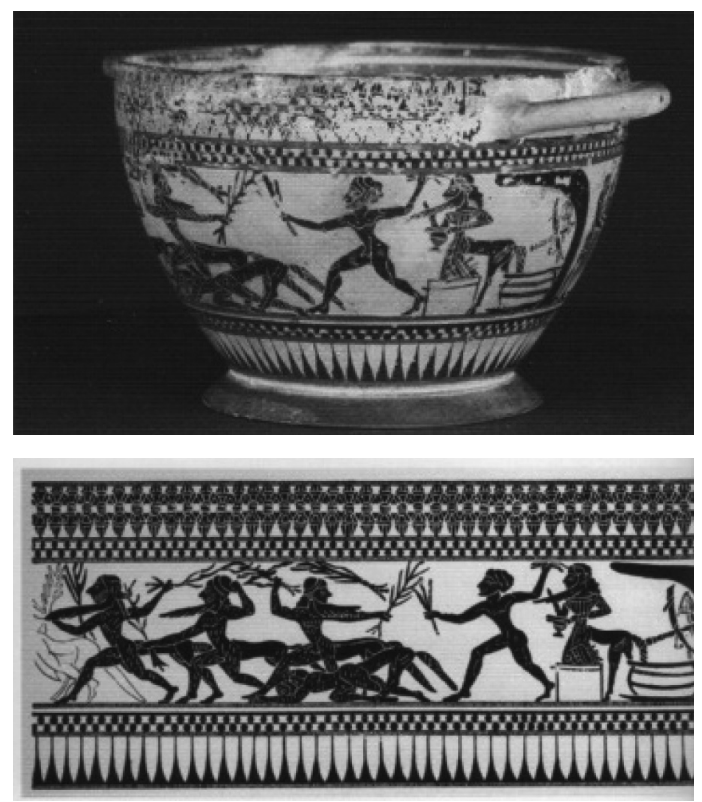

Figuras 7: Héracles e centauros.

A representação de animais e seres híbridos na imagética coríntia passa de uma fase caracterizada por um protagonismo (estilo protocoríntio) para uma fase, no estilo coríntio de pintura, em que tais signos irão preencher as "periferias" dos vasos. Nas "margens" e "limites" dos vasos, afloram o "espaço do fabuloso", no qual a alteridade, sedução, selvageria e o agon (disputa) marcam as transformações durante o século VII a.C. na região do Istmo de Corinto ${ }^{20}$. A passagem do regime aristocrático do génos dos Baquíades para a Tirania dos Cypsélidas provavelmente interferiu nos esquemas artísticos dos pintores do Bairro dos Oleiros na ásty de Corinto $^{21}$ (Schmitt Pantel, 2013, p. 23).

\footnotetext{
${ }^{19}$ Cótylo coríntio. Estilo médio de pintura coríntia, c. 580 a. C. Museu do Louvre. L 173-L 63 (MNC 677).

${ }^{20} \mathrm{O}$ agon é um aspecto que deve ser levado em conta no estudo da imagética grega no período arcaico. Disputas e trocas entre oficinas de diferentes especialidades promoveram uma circulação de signos, de representações e de técnicas artesanais. As pesquisas de Francis Croissant apontam para o exame cuidadoso dos contatos e conexões entre artesãos de uma mesma pólis e de artífices de culturas diferentes. (Croissant, 1999)

21Pauline Schmitt Pantel explica que o trabalho do artesão em sua oficina é sensível às transformações de sua sociedade: “(..) as imagens são um 'espetáculo social', elas colocam em cena um conjunto de valores, que são os da cidade, haja vista que elas também podem ser, em certa medida, a expressão das tensões, das mudanças que afetam a cidade".
} 


\section{Referências bibliográficas}

AGHION, Irène; BARBILLON, Claire; LISSARRAGUE, François. Héros et dieux de l'antiquité: guide iconographique. Paris: Flamarion, 2008 (1994).

AMYX, D. A. Archaic vase-painting vis-à-vis 'free' painting at Corinth. In: MOON, W.G. (org.) Ancient greek art and iconography. The University of Wisconsin Press, 1983. p.37-52.

AURIGNY, Hélène. Offrandes et fréquentation à Delphes au VIIe siècle. In: ÉTIENNE, Roland (org.) La méditerranée au VII siècle av. J.-C. Paris: De Boccard, 2010. p. 234-249.

BÉLIS, Annie. Les fabricants d'auloi en Grèce: l'exemple de Délos, Topoi, Vol. 8/2, p. 777-790 ,1998. BÉRARD, Claude. Iconographie-iconologie-iconologique, Études de lettres, Fasc 4, p. 5-37,1983. BOARDMAN, John. L'art grec. Paris: Larousse, 1965.

CERTEAU, Michel de. A invenção do cotidiano: 1 artes de fazer. Petrópolis: Vozes, 1996.

COOK, R.M. Greek painted pottery. New York: Routledge, 1997 (1960).

COULIÉ, Anne. La céramique greque aux époques géométrique et orientalisante. Paris: Picard, 2013. CROISSANT, Francis. La Peinture grecque etl'histoire des styles archaïques. In: VILLANUEVA PUIG, Marie Christine et al. Céramique et peinture grecques: modes d'emploi. Paris: La Documentation Française, 1999. p. 257-266.

CROISSANT, Francis. Pour une relecture archéologique du "phénomène orientalisant". In: ÉTIENNE, Roland (org.) La méditerranée au VII siècle av. J.-C. Paris: De Boccard, 2010, p. 361-368. DARAKI, Maria. La merdionysiaque, Revue de l'histoire de religions, fasc. 1, p. 3-22, 1982.

DETIENNE, Marcel. Comparer l'incomparable. Paris: Éditions du Seuil, 2000.

DETIENNE, Marcel; VERNANT, Jean-Pierre. Métis - as astúcias da inteligência. São Paulo: Odisseus, 2008 (1974).

DUBINI, Rachele. Dei nello spazio degli uomini: i culti dell'agora e la costruzione di Corinto arcaico. Roma: L'Erma di Bretschneider, 2011.

DURAND, J. L. Sacrifice et labour em Grèce ancienne: essai d'anthropologie religieuse, ParisRome: La Découverte-École Française de Rome, 1986.

FRONTISI-DUCROUX, Françoise. Du masque au visage: aspects de l'identité em Grècea ncienne. Paris: Flamarion, 1995.

GINZBURG, Carlo. Medo, reverência, terror. São Paulo: Companhia das Letras, 2014.

GRIMAL, Pierre. Dicionário da mitologia grega e romana. Rio de Janeiro: Bertrand Brasil, 2005 (1951).

HOFFMANN, Catherin; BRISART, Thomas. Les offrandes orientales et orientalisantes dans les sanctuaires grecques. Compétition et idéal communautaire. In: ÉTIENNE, Roland (org.) La méditerranée au VII siècle av. J.-C. Paris:, De Boccard, 2010.

HOZ, Javier de. Les écritures. In: ÉTIENNE, Roland (org.) La méditerranée au VII siècle av. J.-C. Paris: De Boccard, 2010.

KARDIANOU, Alexandra. Le cratère corinthien, Métis. N.S. 7, p. 63-74, 2009.

LIMA, Alexandre. C.C (org.) Imagem, gênero e espaço: representações da antiguidade. Niterói: Alternativa, 2014.

LIMA, Alexandre Carneiro Cerqueira. Ritos e festas em corinto arcaica. Rio de Janeiro: Apicuri, 2010. LIMA, Alexandre Carneiro Cerqueira. Pantera e águia: representações de animais nos frisos da Cratera e 630 do Museu do Louvre. In: LIMA, Alexandre (org.) Imagem, gênero e espaço: representações da antiguidade. Niterói: Alternativa, 2014. p.147-159.

LISSARRAGUE, François. La cité des satyres: une anthropologie ludique (Athènes, $\mathrm{VI}^{\mathrm{e}}-\mathrm{V}^{\mathrm{e}}$ siècleavant J.-C), Paris, Éditions de L'École des Hautes Études en Sciences Sociales, 2013. p.29-40. LISSARRAGUE, François. Ler e olhar a imagem: balanço e perspectivas de pesquisa sobre a imagética grega. In: LIMA, Alexandre Carneiro Cerqueira (org.) História e imagem: múltiplas leituras, Niterói: Editora da UFF, 2013.

LISSARRAGUE, François. Un flot d'images: une esthétique du banquet grec. Paris: Adam Biro, 1987. MOSSÉ, Claude. Les mythes grecs. Paris: Nathan, 1991.

SCHMITT PANTEL, Pauline. 'Imagens e história grega'. In: LIMA, Alexandre Carneiro Cerqueira. (org.) História e imagem: múltiplas leituras. Niterói: Editora da UFF, 2013. p.9-28.

PAYNE, Humphry. Necrocorinthia: a study of corinthian art in the archaic period. Oxford: Clarendon Press, 1931.

POTTIER, Edmond. Vases antiques du Louvre. Paris: Hachette, planche 49, 1897. 
SCHNAPP, Alain. Eros en chasse. In: BÉRARD, Claude et al. La cité des images: religion et société en Grèce ancienne. Paris: Fernand Nathan, 1984. p.67-84.

SEEBERG, Axel. Corinthian komos vases, Bulletin of the institute of classical studies of the university of London, Supl. 27, n. 216, 1971.

THEML, Neyde. Temênida sherodotiano - mito e rito de fundação da realeza dos macedônios: o passado presente, Hélade 1 (1), 2000. Disponível em http://www.heladeweb.com/N12000/ neyde_theml.htm.

TORELLI, Mario. Storia degli etruschi. Roma-Bari:Laterza, 1999 (1981).

VIDAL-NAQUET, Pierre. Le chasseur noir et l'origine de l'éphébie athénienne. In: Le chasseur noir. Paris: La Découverte, 2005 (1981).

WARBURG, Aby. A renovação da antiguidade pagã. Rio de Janeiro: Contraponto, 2013 (1932). 